\title{
耳下腺多形腺腫再発症例の検討
}

\author{
山下＼cjkstart敏夫・友田 幸一・井野千代徳 \\ 山脇 利朗・熊澤 忠躬
}

\section{Recurrent Pleomorphic Adenomas of the Parotid Gland}

Toshio Yamashita, Koichi Tomoda, Chiyonori Ino,

Toshio Yamawaki and Tadami Kumazawa

(Kansai Medical University)

The clinical courses, pathological findings and methods of therapy of 9 patients with recurrent benign pleomorphic adenoma of the parotid gland are discussed and compared with 187 non-recurrent cases treated between 1976 and 1991. Of the 9 patients, 6 were first recurrence case and 8 had received surgical enucleation as a primary operation. The mean interval to first recurrence was 9 years (range $3 \sim 18$ years).

Total or partial parotidectomy was performed, and all 9 patients are well ( 5.5 years, on the average, after surgery). The histologic characteristic encountered most frequently in the recurrent tumors was a myxoid stroma. The cause of recurrence is most probably an inadequate initial surgical procedure; therefore, partial parotidectomy with preservation of the facial nerve is proposed as an ideal operation for benign tumors of the parotid gland.

Key words: recurrent pleomorphic adenoma, parotid gland, surgery, pathology

はじめに

耳下腺多形腺腫の被膜は直接腫瘍とつながり, 被膜の破壊は腫瘍巣の破壊を意味する。さらに かなりの症例で被膜内に腫瘍細胞巣とその辺縁 の不規則な増殖がみられ，このことが多形腺腫 が良性であるにもかかわらず，再発を起こす一 因と考えられる11。事実，約 50 年前までは耳下 腺多形腺腫の手術は核出術が主であり, その再 発率は約 $40 \%$ とまさに破滅的な成績であった。 その後, 顔面神経保存下浅葉切除術がこの腫瘍 に適用される様になり，その再発率は約 $2 \%$ と 激減した2). しかし，この同じ浅葉切除術でも Woods ら ${ }^{3)}$ は1940〜1954年の434症例で $8 \%$ に 再発したが，1955年～1969年の388症例ではそ
の再発率は $2 \%$ に改善したといい，このことは 手術手技の習熟がその成績に反映することを示 している。また Maran ら4)は19例の，高橋ら5) は 6 例の再発例を報告し, 著者らも 9 例の再発 例を経験したが，それらの初回手術はいずれも 他施設で行われたもので，自施設での手術例に は再発を認めていない。これらのことから，耳 下腺多形腺腫の術後再発防止には, 初回手術方 法の正しい選択と習熟した手技による施行がい かに大切であるかといらことがいえる.

著者らは過去15年間に当科で経験した耳下腺 多形腺腫再発症例 9 例の臨床像, 手術法, 病理 組織像を検討すると共に，再発を防ぐための今 後の手術のあり方について考察を加えたい。 


\section{症例}

当科で1976年から1991年までの15年間に手術 的治療を行った耳下腺腫瘤は, 良性腫瘍298例, 悪性腫瘍71例, 特殊炎症性病変48例の計417例 であった．良性腫瘍298例のらち多形腺腫は196 例で，そのらち9例が再発症例であり，いずれ もその初回手術を他施設で施行された症例であ った. 残りの187例の初回手術当科施行例のう ち，5年以上経過観察し得た 112 例全例に再発 を認めなかった。

\section{臨 床 像(表 1)}

再発症例 9 例中男性 2 名，女性 7 名であった.

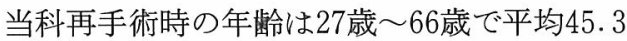
歳であった。またそれらの症例の初回手術時の 年歯は 17 歳〜 58 歳で平均 34.1 歳であった。 ちな みに当科初回手術187例の手術時の年齢は 4 歳 〜88歳で平均 44.9 歳であった。

再発症例 9 例中今回が初めての再発例は 6 例, 2 回目の再発例が 3 例であった。手術術式とし ては初回手術が核出術であったのが 8 例，浅葉 切除術が 1 例であった。な衫，再々手術例の 3 例では, 2 回目の手術は浅葉切除術が施行され ていた。初回手術から 2 回目の手術までの間隔 は 3 年〜 18 年で平均 9 年であった.

再発症例の診断のために, CT シアログラフ ィー(シアロ CT), 超音波検査, ${ }^{99 \mathrm{~m}} \mathrm{Tc}$ 㧊よび
${ }^{67} \mathrm{Ga}$ によるシンチグラフィーが全例に施行さ れた。なかでもンアロ CT は腫瘍の進展範囲や 残存耳下腺組織との関係を知る上で有用であっ た（図 1 ）。超音波検査は腫瘍の多発性を知る上 で，また ${ }^{67} \mathrm{Ga}$ ンンチは腫瘍の悪性度を知る上 で有用でめった。

\section{手術方法および術後成績(表 1 )}

9 例中 3 例に浅葉切除術を，6例に全摘出術 を施行し，そのうち 4 例には顔面神経分枝の一 部切除扣よび神経移植を施行した。術後，1 年 $\sim 10$ 年, 平均 5.5 年の経過観察で全例に再々発

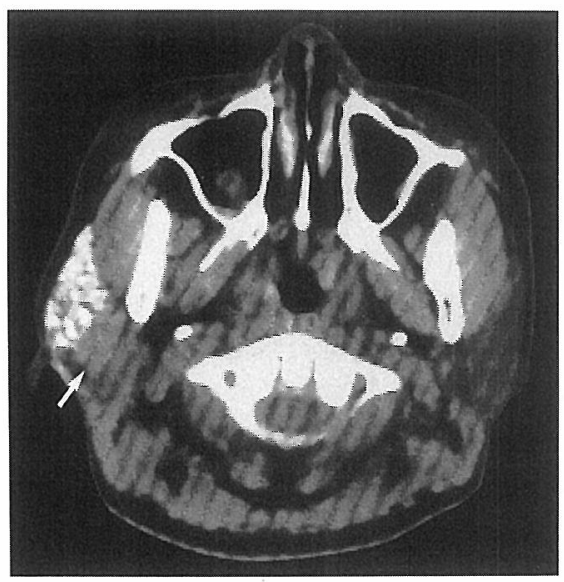

図 1 症例 3 のシアロ CT 像 深葉に辺縁不整の腫瘍を認める (矢印).

表 1 再発性耳下腺多形腺腫 9 症例の病歴, 経過

\begin{tabular}{|c|c|c|c|c|c|c|}
\hline 症例 & 年齢 & 性 & 前回手術 & 再発期間 & 今 回手 術 & 経 \\
\hline 1 & 40 & 女 & 浅葉切除 & 3年 & 全摘出＋神経移植 & 3年, 再発 $(-)$ \\
\hline 2 & 43 & 女 & 核 出 & 5年 & 浅葉切除＋神経移植 & 5年, 再発(一) \\
\hline 3 & 27 & 男 & 核 出 & 6年 & 全摘出＋神経移植 & 6年, 再発 $(-)$ \\
\hline 4 & 65 & 女 & 核 & 18年 & 全摘出 ～～～～～ & 7年, 再発 $(-)$ \\
\hline 5 & 35 & 女 & 核 出 & 8年 & 浅葉切除 & 7年, 再発 $(-)$ \\
\hline 6 & 39 & 女 & (1) 核葉切出 & $\begin{array}{l}16 \text { 年 } \\
8 \text { 年 }\end{array}$ & 全摘出 & 9年, 再発(一) \\
\hline 7 & 37 & 男 & (1) 核葉切出 & $\begin{array}{l}5 \text { 年 } \\
9 \text { 年 }\end{array}$ & 全摘出 & 10年, 再発 $(-)$ \\
\hline 8 & 56 & 女 & (1) 核出出 & $\begin{array}{l}\text { 12年 } \\
\text { 5年 }\end{array}$ & 全摘出 & 2年, 再発 $(-)$ \\
\hline 9 & 66 & 女 & 核 出 & 8年 & 浅葉切除＋神経移植 & 1年, 再発 $(-)$ \\
\hline
\end{tabular}


をみていない，顔面神経麻痺は，神経非切除 5 例中 1 例に一時的な不完全麻痺を認めたが，数 週で回復した，神経切除，移植を行った 4 例は 術後約 6 カ月で洼湆元に回復した.

再発例では腫瘍が多発することがある。自験 例 9 例中 6 例の腫痬は多発性であった。 とくに 症例 7 では最小直径数 $\mathrm{mm}$ の ものから最大直 径 $3 \mathrm{~cm}$ のものまで, 残存耳下腺組織中にまさ に散乱した状態で数十個の腫瘍が認められた (図 2 ).

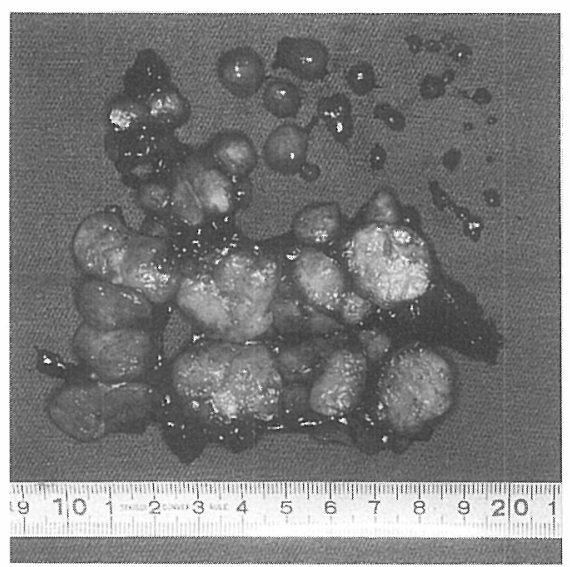

図 2 症例 7 の摘出標本 多発性の腫瘍結節を示す。

\section{摘出標本の病理組織学的観察 (表 2 )}

9 例全例 myxochondromatous pattern (粘液 軟骨腫型)の組織型を有し，うち 2 例は腺管構 造がみられ tubular pattern (腺管型) と考兄ら れる組織形態を混じていた。腫痬は滦注全例で 多結節性飞増殖し，比較的薄い被膜有し，被 膜内にも腫瘍細胞の浸潤が認められた（図 3 ， 4)）９例中 5 例では腫瘍の脂肪織あるいは血 管内への浸潤が文られ(図 5 ), また 3 例では腫 瘍細胞汇異型性がみられ低悪性度を疑ら所見も 観察された。さらに興味ある所見として，穿刺 吸引細胞診が行われた症例 1 では，腫瘍細胞が

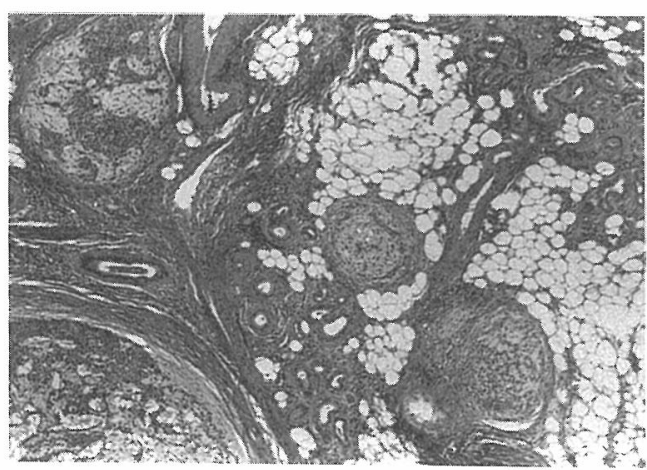

図 3 症例 1 の病理組織像 多結節性增殖と周辺脂肪織への浸潤を示寸。 $(\mathrm{HE}$ 染色, $\times 100)$

表 2 病理組織学的所見

\begin{tabular}{|c|c|c|c|c|c|c|}
\hline 症 例 & 多結節性 & 細胞充実性 & 異型性 & 被膜内浸潤 & $\begin{array}{l}\text { 脂肪織· } \\
\text { 血管内浸潤 }\end{array}$ & 組織パターン \\
\hline 1 & + & & & + & + & $\operatorname{myx}$ \\
\hline 2 & + & & & + & & myx \\
\hline 3 & + & & & + & + & $\operatorname{myx}$ \\
\hline 4 & + & + & + & + & & $\operatorname{myx}$ \\
\hline 5 & + & & & + & + & myx + tub \\
\hline 6 & + & + & + & + & + & $\operatorname{myx}$ \\
\hline 7 & + & & & + & & myx \\
\hline 8 & + & + & + & + & + & $\operatorname{myx}$ \\
\hline 9 & & & & + & & $\operatorname{myx}+$ tub \\
\hline
\end{tabular}

myx : myxochondromatous pattern(粘液軟骨腫型) tub : tubular pattern(腺管型) 


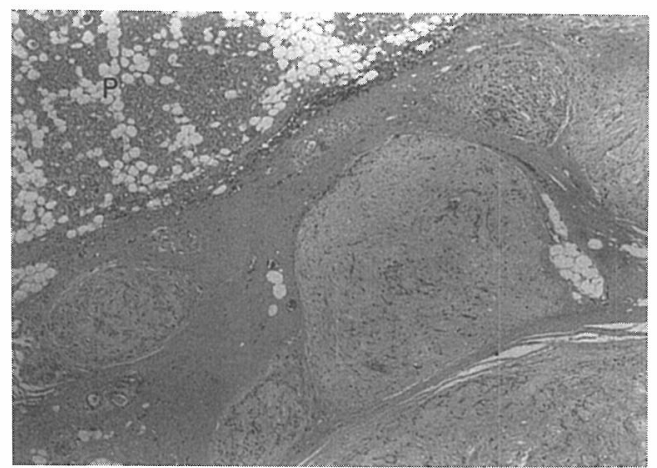

図 4 症例 3 の病理組織像 粘液軟骨腫型の組織型を示し, 被膜内一浸潤し正 常耳下腺 $(\mathrm{P})$ と接する。(HE 染色，×100)

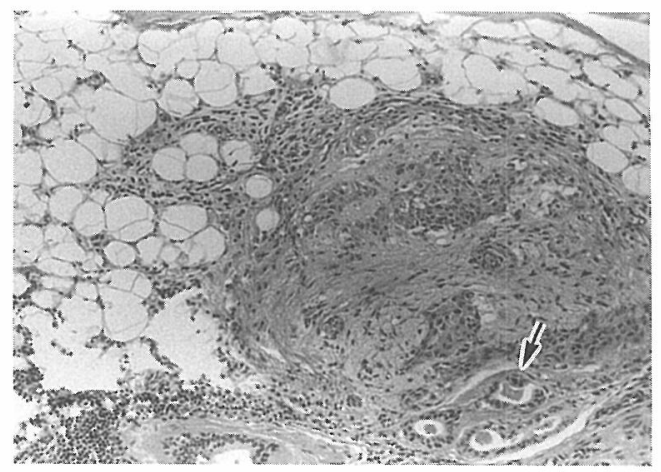

図 5 症例 1 の病理組織像

腫瘍細胞の脂肪織および血管内 (矢印) への浸潤を 示す. $(\mathrm{HE}$ 染色, $\times 200)$

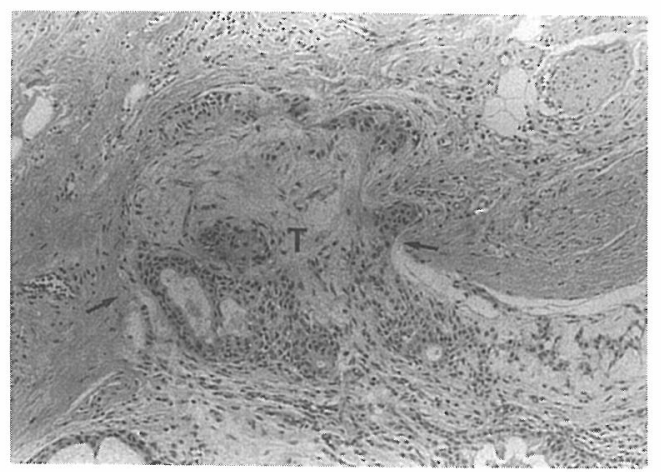

図 6 症例 1 の病理組織像

穿刺部より腫瘍細胞が皮下結合織に浸潤している. $\mathrm{T}$ : 腫瘍部 矢印: 被膜穿刺部 $(\mathrm{HE}$ 染色, $\times 200)$
被膜穿刺部位から皮下結合織へ浸潤寸る所見が 観察された(図 6 ).

\section{考察}

自験再発 9 症例の初回手術時の平均年齢は 34.1歳であった。文献的に再発例初回手術時の 平均年齢は Maran 54) (26.9歳, Niparko 56) は31.4歳, Krolls ら7) は30.4歳, Fee ら ${ }^{8)}$ は30 歳と報告して扣り比較的若年者に多いことがわ かる。ちなみに耳下腺多形腺腫全体の手術時の 平均年齢は Maran 5 () $^{2} 51.4$ 歳とし, 著者ら の結果は44.9歳であった。若い人の方が術後の 観察期間が長く，したがって再発率も高くなる との見方もできるが，それ以上に若年者の多形 腺腫には本質的に再発しやすい傾向があると考 光るのが妥当の様である778).

再発までの期間について検討すると，自験例 では平均 9 年, Maran 54) は平均 4.37 年, 高 橋ら5) ている.ささらに Niparko ら ${ }^{6)}$ は初回手術術式に より再発までの期間が異なるとし，具体的には 核出術で平均 4.9 年, 浅葉切除術で10.6年, 全 摘出術で10.1年, 全摘出術十顔面神経切除術で 12.7年としている。いずれにせよ，再発率を検 討するにはかなり長期間の経過観察が必要と考 克られる。

多形腺腫再発症例の診断上, 最も大切なこと は前回治療の内容, とくに, 前回手術時摘出標 本の病理組織像に関する情報を詳しく入手する ことである。また再発腫瘍は耳下腺周团に浸潤 することが多く，とくに副咽頭間隙への浸潤の 診断には CT が特に有用である。また，後述す るように再発腫瘍には悪性化が時にみられ，そ の意味でも術前の悪性度診断として ${ }^{67} \mathrm{Ga}$ シン チグラフィー拉よび超音波検査は必要であろう。

再発症例の手術術式に関して，当科では耳下 腺全摘出術が主で，腫瘍が完全に浅葉に限局し ていた 3 例に限り，浅葉切除術を行った。また 5 例には顔面神経を保存し得たが，4例では腫 瘍との癒着が強く，一部の分枝を切除せざるを 得なかった。一般に再発症例の手術術式として 
は, 顔面神経を可及的に保存して耳下腺全摘出 を行らのが良いとされている. 一方 Conley ら ${ }^{9)}$ はさらに積極的に顔面神経も切除すべきと し, その理由として, 再発例に悪性化が多いた めとしている.この再発例の悪性化については Buxton ら 10)の47.7\%といらきわめて高い報告 があるが，だいたい10\%以下で8)9111)，最も少な いものでは Eneroth ら ${ }^{12)}$ の $1.6 \%$ とい報告が あり，その頻度はあまり高くないといえる、し たがって可能であれば顔面神経は保存するとい う方針の方が良いと著者らは考えている.

再発腫瘍の多発性について, 自験例 9 例中 6 例に多発性をみた。 その一例は数十個に及ぶも のであった。文献的に Hanna ら ${ }^{13)}$ は15.6\%に， Maran ら4) は63.1\%に, Conley ら9)は64.3\% に，多発性腫瘍を報告している。これらのこと から手術に際しては, 少なくとも浅葉切除術は 施行して执いた方が再々発防止のために必要と 思える。また，数十個に及ぶ多発例の経験から， 初回手術時に, 被膜をまちがっても破らない注 意がぜひ必要で, もし破ってしまった場合は腫 瘍摘出後の徹底的な洗滌を行らべきと考学る。

術後の再々発については, 自験例では最長 10 年から最短 1 年の経過観察で全例とも認められ なかった。 一方Fee ら な $^{8}$ は35\%に再々発をみた とし, Niparko ら ${ }^{6)}$ は48例の再発例のうち実に 32例に再々発をみたとしている.この32例中 11 例は再々発に10年以上経過して出現したとして いることから, 自験例についても今後より長期 間にわたる経過観察が必要と思われた.

術後の最も問題となる副障害として顔面神経 麻痺がある。自験例で術中顔面神経を保存でき た 5 例中， 4 例は麻痺がなく，1例に一時的な 不全麻痺を認めた。顔面神経分枝を切除し, 神 経移植をした 4 例は術後顔面神経麻痺を来した が，約 6 力月で㜔治した。文献的にも Hanna $5^{13)}$ は再発例の術後顔面神経麻痺発生 率は, 初回手術例の8 倍に及ぶとしている。初 回手術で生じた組織の線維化がしばしば腫瘍と 顔面神経との癒着を生じさせ, これが顔面神経
発見のための指標を探しにくくし，また見つか っても, その剝離を困難にするため, 再発手術 例では術後顔面神経麻痺が高頻度に発生するも のと思われる.

腫瘍の病理組織学的検討では, 自験例 9 例中 8 例に多結節性病変を認めた. 村上 ${ }^{14)}$ は 10 例 中 4 例, 高橋ら ${ }^{5)}$ は 6 例中 4 例に認めたと報告 している。また粘液軟骨腫型組織像については, 自験例 9 例中全例で観察され, 村上 ${ }^{14)}$ は10例 中 8 例に認めたと報告している.この二つは再 発例の特徴的所見亡考光る. 一方, 腫瘍細胞の 被膜内浸潤については，自験例全例でみられた のに対して, 村上 ${ }^{14)}$ は10例中 1 例, 高橋ら5) は 6 例中 3 例と少ない，その理由として微小浸潤 の程度をどの様に扱らかによって結果が異なる ものと考える。いずれにしても，多形腺腫が再 発しやすい要因として，Thackray ら ${ }^{15)}$ あるい は村上 ${ }^{14)}$ も指摘している様に，不完全な摘出 により被膜が損傷され，粘液腫成分が周囲に散 布されるためと考えられる。したがって生検, あるいは穿刺吸引細胞診による被膜損傷には充 分注意する必要がある。

また脂肪織や血管内への浸潤も9 例中 5 例に みられた事より, 再発例の手術はかなり広、範 囲で摘出するか，全摘が望ましいと考える.

一方細胞の充実性あるいは異型性については 自験例 9 例中 3 例に低悪性度を認めたが, 村 上 ${ }^{14)}$ も報告している様に再発との間に関連性 はないものと考える.

以上述べた様に多形腺腫再発例の取扱いはな かなか困難である、したがって、いかに再発し ない様に初回手術を行らかが最重要問題である. 自験再発例では前回の手術が核出術であったも のが最も多く，したがって核出術は多形腺腫が 疑われるときには行うべきでない。しかし浅葉 切除術でも 4 例の再発があった。 また文献的に Niparko $5^{6)}$ は再発症例48例中36例に初回手術 として核出術が行われていたが，しかし 7 例は 浅葉切除術が行われていたとしている。したが って浅葉切除術といえども再発があるわけで, 
完全な手術法とはいえない，著者らが行った多 形腺腫初回手術例で， 5 年以上経過観察できた 112例については幸いにも全例再発を認めなか った。したがって著者らが行っている顔面神経 保存部分切除術は再発防止のために一応満足す べき手術と考えている．以下この方法の概 略16)17)を紹介する.

型のごとく耳前部に S 字切開を入れ，耳下腺 全貌を露出, 次いで耳下腺外側面を乳様突起お よび胸鎖乳突筋から剥離後, 顔面神経の主幹を 明視野に置く．曲ペアンの背部を神経に沿わせ， その開大により耳下腺内で顔面神経をトンネル 式に一部露出する.次に浅葉に腫瘍が存在する 場合には, 浅葉内の腫瘍の位置関係を確認後, 顔面神経を保護し，トンネルの浅部の葉組織を 腫瘍から十分離れた部位で切離する.この操作 によって，末梢の顔面神経がさらに明視下に置 かれる、そこでトンネル式にさらに末梢の顔面 神経を露出させ, その浅部の葉を切離する.こ の操作の繰り返しにより, 顔面神経を明視下に 保護しつつ, 正常耳下腺組織を付けた腫瘍の摘 出が可能となる。腫瘍が深葉にある場合には, 同様の操作で顔面神経を露出後, 同神経を輪ゴ ムで吊り上げ，深部にある腫瘍を可及的に正常 組織を付けて摘出する. 浅・深葉いずれの場合 も, 腫瘍摘出後は残存腺組織の両断面を縫縮す る.腫瘍が大きいため切除後腺組織があまり残 らずこの縫縮が不可能な場合は，胸鎖乳突筋の 一部を折り返して, 欠損耳下腺部を被覆する. 最後に術創に持続吸引ドレーンを挿入し, 皮膚 縫合を行ら.

以上の方法は顔面神経を保存し, 必要な耳下 腺組織のみを腫瘍に付けてとる en bloc 手術と 考えられる。ただ，浅葉切除術と共通していえ ることだが，この方法にも完全でない点がある. すなわち, 腫瘍が大きいか, あるいは発生部位 の関係で, 被膜が直接顔面神経と接している時 には，腫瘍が良性であるだけに，どうしても顔 面神経保存が第一義となり，その部分では被膜 に沿った切除を行わざるを得ない。これがこの
部分切除術の限界である.しかし習熟した，か つ注意深い切除によって充分再発が防げると考 える。

\section{まとめ}

当科で1976年から1991年までの15年間に手術 的治療を行った良性多形腺腫196例のらち9例 が再発症例であり，いずれもその初回または再 手術を他施設で施行された症例であった.

再発症例 9 例中初回再発例は 6 例, 再々発例 は 3 例であった。初回手術が核出術であったも のが 8 例, 浅葉切除術が 1 例であった. 初回手 術から 2 回目の手術までの間隔は平均 9 年であ った。

9 例中 3 例に浅葉切除術を, 6 例に全摘出術 を施行し, 術後平均 5.5 年の経過観察で全例に 再々発をみていない。

本論文の要旨は第12回日本頭頸部腫瘍学会(横浜) にて発表した.

\section{参考文献}

1）奥田 稔, 坂口幸作 : 耳下腺腫瘍の診断と治療. 耳鼻臨床 $79: 867 \sim 879,1986$.

2) Donovan DT and Conley JJ : Capsular significance in parotid tumor surgery; reality and myths of lateral lobectomy. Laryngoscope $94: 324 \sim 329,1984$.

3) Woods JE, Chong GC and Beahrs OH : Experience with 1360 primary parotid tumors. Am J Surg $130:$ 460 462, 1975.

4) Maran AGD, Mackenzie IJ and Steanley RE : Recurrent pleomorphic adenoma of the parotid gland. Arch Otolaryngol 110: 167 171, 1984.

5）高橋光明, 熊井恵美, 上戸敏彦, 他 : 耳下腺多 形腺腫再発症例の臨床病理学的検討. 日耳鼻 $94: 489 \sim 494,1991$.

6) Niparko JK, Beauchamp ML, Knause CJ, et al : Surgical treatment of recurrent pleomorphic adenoma of the parotid gland. Arch Otolaryngol Head Neck Surg $112: 1180 \sim 1184$, 1986.

7) Krolls $\mathrm{S}$ and Boyer R: Mixed tumors of salivary gland; long-term follow up. Cancer 
$30: 276 \sim 281,1972$.

8) Fee W, Goffinet D and Calcaterra T : Recurrent mixted tumors of the parotid gland; results of surgical therapy. Laryngoscope $88: 265 \sim 273,1978$.

9) Conley J and Clairmont A : Facial nerve in recurrent benign pleomorphic adenoma. Arch Otolaryngol Head Neck Surg 105 : 247 251, 1979.

10) Buxton R, Maxwell J and French A : Surgical treatment of epithelial tumors of the parotid gland. Surg Gynecol Obstet 97 : 401 416, 1975.

11) Foote $F$ and Frazell $E$ : Tumors of the major salivary glands. Cancer $6: 1065 \sim 1133,1963$.

12) Eneroth CM, Blanck $C$ and Jakobsson PA : Carcinoma in pleomorphic adenoma of the parotid gland. Acta Otolaryngol 66 : 477 492, 1968.

13) Hanna DC, Dickason WL, Richerdson GS, et al : Management of recurrent salivary gland tumors. Am J Surg 132: 453 458, 1976.

14）村上正文：唾液腺腫瘍の臨床病理学的および免 疫組織学的研究. 日耳鼻 $91: 247 \sim 261,1988$.

15) Thackray $A C$ and Lucas $R B$ : Recurrent pleomorphic adenoma. Tumor of the major salivary glands. Atlas of Tumor Pathology Second Series, Fasicle 10 (ed by Firminger HI). pp $35 \sim 39$, Armed Forces Institute of Pathology, Washington DC, 1974.

16）山下敏夫 : 耳下腺浅葉切除. JOHNS 1:417～ 421, 1988.

17）山下敏夫：耳下腺良性腫瘍手術一部分切除か 葉切除か一. 口咽科 $2: 23 \sim 27,1990$.

\footnotetext{
原稿受付 : 平成 4 年 2 月 14 日 原稿採択: 平成 4 年 3 月 30 日 別刷請求先 : 山下敏夫 厂570 守口市文園町 1

関西医科大学耳鼻咽喉科学教室
} 